University of South Carolina

Scholar Commons

8-1988

\title{
Opposition to Human Rights Treaties in the United States Senate: The Legacy of the Bricker Amendment
}

Natalie Hevener Kaufman

David Whiteman

University of South Carolina - Columbia, whiteman@sc.edu

Follow this and additional works at: https://scholarcommons.sc.edu/poli_facpub

Part of the Political Science Commons

\section{Publication Info}

Published in Human Rights Quarterly, Volume 10, Issue 3, 1988, pages 309-337.

This Article is brought to you by the Political Science, Department of at Scholar Commons. It has been accepted for inclusion in Faculty Publications by an authorized administrator of Scholar Commons. For more information, please contact digres@mailbox.sc.edu. 


\title{
Opposition to Human Rights Treaties in the United States Senate: The Legacy of the Bricker Amendment
}

\author{
Natalie Hevener Kaufman and David Whiteman*
}

My purpose in offering this resolution is to bury the so-called covenant on human rights so deep that no one holding high public office will ever dare to attempt its resurrection.'

Senator John Bricker (R-Ohio), 1951

As we consider the status of the human rights covenants today, it would appear that the ghost of Senator John Bricker must be smiling at the fulfillment of his wish. Thirty years after the defeat of the Bricker Amendment, the covenants and most other major human rights treaties have yet to receive Senate approval. ${ }^{2}$ During the same period, these covenants have been ratified by eighty-five other nations, including fifteen Western democracies. ${ }^{3}$ The question which deserves our attention is why the United States has not ratified these treaties as well. The United States has long considered itself the leading protector of human rights. Many Americans consider the Declaration of Independence and its references to "inalienable rights" to be the source of reintroduction of basic human rights into the modern political

\footnotetext{
*We would like to thank Louis Sohn, Jerel Rosati, and Paul Gordon Lauren for their helpful comments on this article.

1. Congressional Record. 82nd Cong., 1st sess., 1951. Vol. 97, pt. 8, 8263.

2. Some human rights treaties have been ratified. Two treaties from the early 1950s, the Convention on the Political Rights of Women and the Inter-American Convention on the Granting of Political Rights to Women, were ratified in 1975. In 1968, the Senate ratified the Supplementary Slavery Convention, which extended the 1926 Slavery Convention and its Protocol. Some scholars would also include the four Geneva Protocols which cover wartime conditions and the Protocol on the Status of Refugees.

3. United Nations, Multilateral Treaties Deposited with the Secretary General: Status as of 31 December 1986 (New York: United Nations, 1986). Western democracies ratifying the covenants are: Australia, Austria, Canada, Denmark, Finland, France, the Federal Republic of Germany, Iceland, Italy, the Netherlands, Norway, Portugal, Spain, Sweden, and the United Kingdom.
} 
scene. Most Americans believe that the United States has the best record on human rights of any country in the world. When these treaties appear to reflect the highest ideals of the American people, and when our allies and other democracies have been able to reconcile their political and legal systems with the obligations of the treaties, why is the United States still unable to do so?

The purpose of this analysis is to explore in a systematic fashion (1) the original development of arguments in opposition to human rights treaties in the United States Senate and (2) the residual strength of these arguments in contemporary deliberations. We base our findings on legal analysis, legislative histories, content analysis of congressional hearings, and interviews with congressional staff members. Our main conclusions are that proponents of the Bricker Amendment were primarily concerned with human rights treaties, that contemporary arguments against passage of human rights treaties have not changed substantially from arguments presented in the 1950s, and that the legacy of these earlier deliberations is still apparent in the attitude of those considering the treaties now.

Certainly, given the political environment of the 1950s, some suspicion of human rights treaties might have been expected. Two aspects of the environment were particularly salient: the movement toward racial integration and the Cold War. The integration of American troops abroad during World Ward II and the establishment of a wartime Fair Employment Practices Commission were small steps which signalled the clear possibility of impending federal action to eliminate racial discrimination. The report of the Truman Commission on Civil Rights urged federal action to address the country's racial problems. Legislation was introduced into Congress to make lynchings a federal offense and to eliminate the poll tax. The Supreme Court by 1950 was hearing cases challenging Plessy $v$. Ferguson, and in 1952, the Justice Department submitted amicus curiae briefs criticizing segregation in education. While proponents of these civil rights measures were skeptical about their success, conservatives took very seriously any discussion of federal action to dismantle segregation within the states. States' rights were ardently defended as the only bulwark against an expansive federal government which would impose a host of liberal programs, including the elimination of racial restrictions on marriage, property ownership, and education.

If civil rights were the domestic aspect of the political environment most relevant to treaty consideration, the Cold War was the major international aspect. To conservatives of the time, the essence of the United States was clearly threatened by communists. McCarthyism was one extreme manifestation of concern that a worldwide communist movement, directed from Moscow, was taking power on a global scale, and that the United States was the only country with the capability and potential will to halt the menace. Certain major events contributed to these fears. With the explosion of a 
Soviet nuclear device in 1950, the atomic monopoly of the United States disappeared. The entire Korean operation, including the effective North Korean resistance, heightened fears of communist power and the inability of the United States to confront and resist it. The ascendence of the Communist Party in China, when joined with the assumption of Sino-Soviet friendship and cooperation, was interpreted by conservatives as seriously damaging United States influence and security.

The effect of these conservative concerns can be seen clearly in deliberation over human rights treaties in the 1950s. Human rights treaties received their most extensive review by the Senate during this period in debate over the so-called Bricker Amendment. Opponents of the treaties, led by Senator Bricker, focused their efforts on the adoption of a constitutional amendment which was primarily motivated by the alleged danger arising from these treaties. Although international legal scholars have often acknowledged this connection between the human rights treaties and the effort in the early 1950 s to amend the treaty-making provisions of the Constitution, most international relations scholars have not. Most major works on American foreign policy which mention the Bricker Amendment imply that its major purpose was the curtailment of the president's power to conclude executive agreements. ${ }^{4}$ One objective of this research, then, is to clarify the relationship between the Bricker Amendment and human rights treaties. We contend that, while criticism of the increased use of executive agreements was reflected in one section of the amendment and did become an important issue during the debates, the original impetus for the Bricker Amendment was a concern about the United Nations human rights treaties. And it was in the context of the Bricker Amendment controversy that these treaties were branded as dangerous to the American way of life and cast into a Senatorial limbo from which they have never really been released.

4. Of the major foreign policy writers who treat the Bricker Amendment, the following view it primarily as an attempt to curb the use of executive agreements: Merlo Pusey, Eisenhower the President (New York: MacMillan Co., 1956), 231; Ronald Stupak, American Foreign Policy (New York: Harper and Row, 1976), 112; Alexander Deconde, A History of American Foreign Policy (New York: Charles Schribner's Sons, 1971), 778; Charles Kegley and Eugene Wittkopf, American Foreign Policy-Pattern and Process (New York: St. Martin's Press, 1982), 416; John Rehm, "Making Foreign Policy through International Agreement," in The Constitution and the Conduct of Foreign Policy, Francis Wilcox and Richard Frank, eds. (New York: Praeger Publishers, 1976), 128; John Spanier, "Congress and the Presidency: The Weakest Link in the Policy Process," in Congress, the Presidency, and American Foreign Policy, John Spanier and Joseph Nogee, eds. (New York: Pergamon Press, 1981), xix.

Other writers link the Bricker Amendment to: congressional nostalgia for lost power (Walter Murphy, Congress and the Court (Chicago: University of Chicago Press, 1962), 258); an attempt to restrict presidential freedom to commit U.S. troops overseas (John Spanier and Eric Uslander, How America Foreign Policy is Made (New York: Praeger Publishers, 1975), 81); and a neo-isolationist movement to curtail U.S. internationalism (Louis Gersan, "J. F. Dulles," The American Secretaries of State and Their Diplomacy, XVIII, Robert Ferrell, ed. (New York: Cooper Square Publishers, 1967), 118-22). 
Prior to consideration of the Bricker Amendment, the only extensive postwar Senate deliberations on human rights treaties concerned the Genocide Convention. Many of the arguments both for and against the Genocide Convention are specific to it, and therefore these deliberations are not a good source for general arguments against human rights treaties. Nevertheless, the deliberations are important because they marked the emergence of a small but strong group of opponents who, despite the overwhelming support for the Convention from many and varied individuals and organizations, managed to block the treaty. ${ }^{5}$ Even at this early point, opponents did not consider the Genocide Convention to be an isolated problem, but part of a much larger movement-the international recognition and legal codification of individual human rights-which they feared would alter the nature and process of the American political system and the American way of life. The arguments that germinated during the Genocide Convention hearings later blossomed into full-fledged opposition to all human rights treaties.

The remainder of the article is divided into four sections. The first section is an analysis of the Bricker Amendment itself, highlighting the explicit and implicit arguments against human rights treaties. Second, we summarize Senate consideration of the Bricker Amendment. In the third section, we offer a typology of arguments made in the 1950s against ratification of human rights treaties. Fourth, we consider contemporary opposition to the treaties, assessing the stability of arguments over time and the factors now inhibiting passage.

\section{THE BRICKER AMENDMENT}

The movement surrounding the proposal, modification, and support of the Bricker Amendment reflected a widespread concern within the American electorate. Garrett identifies two important dimensions of the movement: (1) a "substantive" concern about increasing United States involvement internationally and (2) an "institutional" dismay at the increased power and independence of the executive in foreign affairs. ${ }^{6}$ If we look closely at the

5. Communications supporting the Genocide Convention were received by the Senate from organizations such as the American Federation of Labor, American Legion, American Veterans' Committee, Amvets, Bar Association of the City of New York, Catholic Association for International Peace, Congress of Industrial Organizations, Federal Council of Churches of Christ, General Federation of Women's Clubs, Loyal Order of Moose, NAACP, National Conference of Christians and Jews, National Federation of Business and Professional Women's Clubs, Salvation Army, and United Council of Church Women. For a more extensive list, see U.S. Congress. Senate. Committee on Foreign Relations. Subcommittee on the Genocide Convention. Hearings on the International Convention on the Prevention and Punishment of the Crime of Genocide. 81 st Cong., 2d sess., 1950. S. Rept. 472.

$\rightarrow$ Steve Garrett, "Foreign Policy and the American Constitution: The Bricker Amendment in Contemporary Perspective," Int'l Studies Q. 16:2 (1972): 187-220. 
immediate cause of concern, however, we can see that human rights treaties played the most important role in initiating and maintaining the spirited attack on the treaty-making powers. Opposition to the treaties, of course, reflected both substantive and institutional concerns. The substantive concern focused on the notion that human rights fall within a nation's domestic jurisdiction and are not an appropriate subject for treaty-making. The institutional concern revolved around the issue of the distribution of power between the federal government and the states; human rights fall in the domain of "states' rights" and are, therefore, reserved to the states by the tenth amendment to the Constitution.

One important point to be made is that, although there are many different reasons why various members of the Senate in the 1950s supported the collection of proposals now subsumed under the general term "Bricker Amendment," concern over the effects of human rights treaties was in the forefront. Senator Bricker himself linked his proposal to his opposition to the human rights treaties and their international implementation:

There is a singleness of purpose of course on the part of all of us ... who have joined in the presentation of this Resolution. ... The American people want to make certain that no treaty or executive agreement will be effective to deny or abridge their fundamental rights. Also, they do not want their basic human rights to be supervised or controlled by international agencies over which they have no control.?

Anti-communist and anti-Soviet feelings also provided motivation for the amendment, and often these two fears were linked.

Iron Curtain countries would no doubt welcome a new Roosevelt-Litvinov agreement to make their confiscatory decrees effective in the United States . . . . [R]eactionary one-worlders [are] trying to vest legislative powers in non-elected officials of the UN and its satellite bodies with a socialist-communist majority. ${ }^{8}$

If we examine each section of the 1953 form of the amendment, we can see reflected there a variety of political and legal concerns raised by the human rights treaties.

\section{Section 1}

The first section of the Bricker Amendment simply states: "A provision of a treaty which denies or abridges any right enumerated in this Constitution

7. U.S. Congress. Senate. Committee on the Judiciary Subcommittee on Constitutional Amendments. Hearings on S. R. Res. 1 and S. J. Res. 43, Treaties and Executive Agreements. 83rd Cong., 1st sess., 1953. S. Rept. 2-3. (Cited hereafter as: Senate Judiciary Committee Hearings, 1953.)

8. Senator John Bricker, quoted in "Foreign Policy," Congressional Quarterly Almanac 10 (1954): 245. 
shall not be of any force or effect" (emphasis added). In defending Section 1, Senator Bricker said it would ensure that "no [humanitarian] treaty can be effective to undermine the constitutional rights of American citizens...." ${ }^{\prime \prime}$ The issue here is the nature and extent of the limits on the content of treaties. Some constitutional law scholars had argued that treaties, being the supreme law of the land, were not subject to normal constitutional restrictions. Such would be a broad reading of Article VI, paragraph 2, of the Constitution:

all Treaties made, or which shall be made, under the Authority of the United States, shall be supreme Law of the land; and the Judges in every State shall be bound thereby, any thing in the Constitution or Laws of any State to the Contrary notwithstanding.

Senator Bricker described Section 1 in the following manner:

Section 1 subjects the President and the Senate to constitutional restraints in the exercise of the treaty-making power comparable to those which limit their action as participants in the enactment of ordinary legislation. This was, of course, the original intent of the framers of the Constitution and was reflected in early judicial dicta. ${ }^{10}$

He was referring to the decision in Geofroy v. Riggs, which held that the treaty power does not extend "so far as to authorize what the Constitution forbids." 11 The difficulty, as Senator Bricker viewed it, was the subsequent decision of the Supreme Court in Missouri v. Holland, which left ambiguous the meaning of Article VI, paragraph 2.

Acts of Congress are the supreme law of the land only when made in pursuance of the Constitution, while treaties are declared to be so when made under the authority of the United States. It is open to question whether the authority of the United States means more than the formal acts prescribed to make the convention. ${ }^{12}$

Bricker saw this decision in 1919 as effectively reversing that of Geofroy v. Riggs, and he argued that the lack of clarity on this crucial issue made amendment of the Constitution a necessity. He argued that most of the rights contained in the Bill of Rights would be "repealed" by ratification of the human rights covenant. His amendment would prevent this travesty.

9.-Senate Judiciary Committee Hearings, 1953, note 7 above, 11.

10. John Bricker, "Making Treaties and Other International Agreements," Annals of the American Academy 289 (1953): 137.

11. 133 U.S. 266 (1889).

12. Missouri v. Holland, 252 U.S. 433 (1919). 
The American people resent the argument that rights which they regard as Godgiven and inalienable can be alienated by the President and two-thirds of the Senate present and voting. ${ }^{13}$

\section{Section 2}

It is in Section 2 that we see most clearly the institutional line of attack laid by the Bricker proponents. They wished to secure greater protection for states' rights, arguing the constitutional grounds of the tenth amendment. Section 2 of the Bricker Amendment proposed that:

No treaty shall authorize or permit any foreign power or any international organization to supervise, control, or adjudicate rights of citizens of the United States within the United States enumerated in this constitution or any other matter essentially within the domestic jurisdiction of the United States.

The purpose of this section was to restrain the federal government from further encroaching upon states' rights via the treating-making power. As has already been mentioned, a great concern was the use of these treaties to establish a federal basis for desegregation. This section would have enabled Congress to review all treaties before they would have any domestic application, thereby preventing the federal government from using treaties as a basis for expanding its authority into areas where power is otherwise reserved to the states, under the tenth amendment to the Constitution. This issue arose from one possible interpretation of the Missouri v. Holland decision. The case concerned a treaty between the United States and Great Britain regulating, for conservation purposes, the taking of migratory birds. The state of Missouri challenged the treaty and the implementing legislation on the grounds that it interfered with states' rights and violated the tenth amendment of the Constitution. In upholding the treaty and federal statute, Mr. Justice Holmes stated:

We do not mean to imply that there are no qualifications to the treaty-making power; but they must be ascertained in a different way. It is obvious that there may be matters of the sharpest exigency for the national well being that the act of Congress could not deal with but that a treaty followed by such an act could. ... .

The treaty in question does not contravene any prohibitory words to be found in the Constitution. The only question is whether it is forbidden by some invisible radiation from the general terms of the Tenth Amendment. ${ }^{14}$

13. Senate Judiciary Committee Hearings, 1953, note 7 above, 6 . At the time of these Hearings, there was a single covenant.

14. Missouri v. Holland, 252 U.S. 432 (1919). 
To this question he answered "no." And it is this issue which led to the drafting of Section 2 of the Bricker Amendment. Senator Bricker stated:

Section 2 prevents the President and the Senate from using treaties as an instrument of domestic legislation without the participation of the House of Representatives. In addition, section 2 protects the reserved powers of the states by preventing Congress from acquiring by treaty legislative power which it does not possess in the absence of treaty. . . . [It] reverses the doctrine of Missouri $v$. Holland which holds that a treaty may empower Congress to legislate in areas prohibited by the Tenth Amendment in the absence of treaty. ${ }^{15}$

In addition to states' rights concerns, Section 2 was designed to protect United States domestic jurisdiction. Senator Bricker cited Article 2, paragraph 7, of the United Nations Charter and argued that the human rights treaties were violating this provision.

Are human rights essentially within the domestic jurisdiction? Dr. Philip Jessup and many others who have represented us at the U.N. say, "No." If that is true, then nothing is essentially within the domestic jurisdiction. Those who oppose section 2 must believe that the relationship between the American people and their own government is not purely a domestic matter. ${ }^{16}$

He then explained that this reason was the motivating force behind all his efforts to amend the Constitution.

What this amendment would in essence do is to keep the rights of the American people in the spiritual realm and not place them in the temporal power of an international government which is controlled by countries which are totalitarian in their philosophy and seem to have no concept of the God-given inalienable rights that the people of America enjoy."

\section{Section 3}

A further concern of those supporting the Bricker Amendment was that courts might apply provisions of the human rights treaties directly, without implementing legislation from Congress. Since the treaties, in general, have no explicit provision that they are not self-executing, this interpretation might be possible. Bricker described Section 3 as an effort to prevent the invasion of our domestic jurisdiction through the instrumentality of human rights treaties. Section 3 read: "A treaty shall become effective as internal law in the United States only through the enactment of appropriate legislation by the Congress." Senator Bricker cited the Fujii case as a "reminder that treaties

15. Bricker, note 10 above, 136.

16. Senate Judiciary Committee Hearings, 1953, note 7 above, 9.

17. Ibid., 12. 
may have far-reaching and unintended consequences...$^{18}$ In this case the intermediate California court cited Articles 55 and 56 of the United Nations Charter, as invalidating the state's alien land act. Senator Bricker concluded:

If the Supreme Court of the United States should adopt the reasoning of the lower California Court, thousands of Federal and State laws will be nullified. ... All treaties affecting domestic law must be made non-self-executing to avoid unintentional alteration of the rights of the American people under Federal and State laws. ${ }^{19}$

This section was, in effect, a second line of defense in the event that a human rights treaty was actually ratified by the Senate without a non-self-executing provision or reservation. ${ }^{20}$ Courts, then, would have been prevented from citing treaty provisions that had not been implemented by domestic legislation.

\section{Section 4}

The increase in the use of executive agreements and their effect on the rights of Americans also troubled Senator Bricker and his supporters. Section 4 responded to the fear of abrogation of rights by agreements not submitted to Congress:

All executive and other agreements between the President and any international organization, foreign power, or official thereof shall be made only in the manner and to the extent to be prescribed by law. Such agreements shall be subject to the limitations imposed on treaties, or the making of treaties, by this article.

This section was a reaction to the Supreme Court's decisions in the Belmont and Pink cases. At issue was the Litvinov agreement, signed as part of the settlement surrounding the recognition of the Soviet government. It was not submitted to Congress, and it did result in property transfers which were contrary to the state law of New York. Bricker bitterly presented the case in the following manner:

Foreign creditors were entitled to the protection of the fifth amendment. Both Russia and the United States were powerless to deprive them of that property. However, the Supreme Court held that an agreement between Franklin Roosevelt and Maxim Litvinov cancelled out property rights otherwise protected by the fifth amendment and the public policy of the State of New York. ${ }^{23}$

18. Ibid., 7.

19. Ibid., 7-8.

20. An attachment to the ratification resolution for the Genocide Convention requires exactly this step: that implementing legislation be enacted by Congress before the treaty is officially ratified by the United States.

21. Senate Judiciary Committee Hearings, 1953, note 7 above, 7-8. 
The more general issue was the determination by the Court that: "A treaty is a "law of the land" under the supremacy clause ... of the Constitution. Such international compacts and agreements as the Litvinov assignment have a similar dignity." 22 In other words, executive agreements have the same constitutional status as treaties. Thus, the Bricker forces argued that if human rights treaties and agreements were acceded to by the United States as executive agreements without the consent of the Senate, they could be used to deprive Americans of their basic rights, including the right to private property.

\section{Summary}

In the final analysis, it would appear that the crucial topic of debate became whether or not human rights is an appropriate subject matter for treatymaking. Opposition to the conclusion of human rights treaties came to signify the protection of domestic jurisdiction, the maintenance of states' rights, and the defense against the encroachment of international organizations. As Senator Bricker put it: "the peace of the world is endangered by the U.N.'s ambition to supervise and control the purely domestic affairs of its members. . . ." ${ }^{\prime 23} \mathrm{He}$ specifically attacked the covenant:

the State Department of the previous administration contended that the U.N. draft Covenants on Human Rights were great humanitarian treaties, and that the American people should cheerfully submit their political, civil, and economic rights to United Nations definition, supervision, and control. ${ }^{24}$

\section{FORMAL CONGRESSIONAL DELIBERATIONS}

On 17 July 1951, Senator Bricker made a direct attack on the human rights treaties by proposing that the Senate adopt a resolution that would have required that the president announce that the covenant was unacceptable and withdraw the United States from participation in drafting it and other human rights treaties. In the course of debate, Senator Bricker characterized the covenant as "a Covenant on Human Slavery," a legalization of "the most vicious restrictions of dictators," a "legal basis for the most repressive measures of atheistic tyranny," "an attempt to repeal the Bill of Rights," a threat to freedom of religion, and "a blueprint for tyranny."

22. U.S. v. Pink, 315 U.S. 230 (1942).

23. Senate Judiciary Committee Hearings, 1953, note 7 above, 9.

24. Ibid., 10.

25. Congressional Record. 82nd Cong., 1st sess. 1951. Vol. 97, pt. 8, 8255. 
By 14 September 1951, Senator Bricker moved to introduce a constitutional amendment aimed at protecting the "sacred rights which [U.S. citizens] enjoy under the Bill of Rights and the Constitution." ${ }^{26}$ On 7 February 1952, Senator Bricker introduced, with fifty-nine co-sponsors, a second constitutional amendment. ${ }^{27}$ In introducing the amendment, Senator Bricker made specific mention of the human rights covenants.

There is not the remotest chance that even one-third of the present Senate would undermine the rights of the American people by voting for the U.N. Covenant on Human Rights or any other treaty of similar import. However, the rights and freedoms enumerated in the Constitution must be protected in perpetuity, and not merely by the suffrance of the President and two-thirds of the Senators present and voting. ${ }^{28}$

The Senate Judiciary Committee held hearings on the Bricker Amendment in May and June of 1952. By a vote of nine to five, the Committee approved an amended version, but the Senate adjourned without debating the issue.

On 7 January 1953, Senator Bricker once again introduced a constitutional amendment, this time co-sponsored by sixty-two Senators. ${ }^{29}$ Support had grown for some form of the amendment and passage appeared likely. At the hearings held in 1953 by the Senate Judiciary Committee, the Eisenhower administration expressed its opposition to the amendment through testimony by Secretary of State Dulles. Dulles had the difficult task of reversing himself publicly on human rights treaties. Supporters of the Bricker Amendment had frequently cited a speech by Dulles in which he stated that treaties "can take powers from the States and give them to the Federal Government or to some international body, and they can cut across the rights given the people by their constitutional Bill of Rights." ${ }^{130}$ In an effort to assuage the fears of the Bricker followers and undercut support for the amendment, Dulles made the following conciliatory statement:

This administration is committed to the exercise of the treaty making power only within traditional limits. ... [W] [Wile we [the administration] shall not withhold our counsel from those who seek to draft a treaty or covenant on human rights, we do not ourselves look upon a treaty as the means which we would select as the proper and most effective way to spread throughout the world the goals of human liberty. ... We, therefore, do not intend to become a party to any such covenant or present it as a treaty for consideration by the Senate.... .

26. Ibid., 11361.

27. Congressional Record. 82nd Cong., 2d sess., 1952. Vol. 98, pt. 1, 907-14. Also, Laurence Smith (R-Wisc.) introduced the same amendment into the House on 11 February 1952.

28. Ibid., 908.

29. S.J. 130 was introduced and expired during the 82nd Congress.

30. John Bricker and Charles Webb, "Treaty Law vs. Domestic Constitutional Law," Notre Dame Law Review 29:4 (1954): 531.

31. Senate Judiciary Committee Hearings, 1953, note 7 above, 825. 
He also said that the administration had no intention of recommending ratification of the Genocide Convention. Despite this appeal, the Senate Committee on Foreign Relations voted to approve the amendment.

Floor debate began on 20 January 1954. The Eisenhower administration continued to oppose the Bricker Amendment but had approved a much weaker proposal, the Knowland version, which had been offered as a substitute. $^{32}$ When the votes were finally taken, the Bricker version failed to receive the requisite two-thirds vote for a constitutional amendment-fiftytwo Senators voted in favor, while forty were opposed. ${ }^{33} \mathrm{~A}$ weaker version proposed by Senator George came closer, falling one vote short of the requirement.

What is important to remember in assessing these deliberations is that, while supporters of the amendment were reacting against human rights treaties, opponents of the amendment were not arguing in favor of the treaties. Arguments against the Bricker Amendment had little relevance to the debate over human rights treaties, and the defeat of the Bricker Amendment revealed nothing about support for the treaties. Opponents argued, for example, that the amendment would interfere with the day-to-day conduct of foreign affairs, significantly alter a constitutional balance of power that had worked well for 160 years, endanger national survival, limit the president's ability to conduct and end a war, impede arrangements for the control of atomic energy and nuclear weapons, and embarrass the president in front of both allies and enemies. ${ }^{34}$

Throughout the records of the public debates related to human rights treaties, a single private interest group consistently held a dominant place and deserves special consideration: the American Bar Association (ABA). ${ }^{35}$ The determination within the $A B A$ that human rights treaties posed a threat to Americans' basic rights and to their system of government was crucial to the popularity of the Bricker proposal. In introducing the amendment in 1953 Senator Bricker said:

I should like to pay tribute to the magnificent work of the American Bar Association and its Committee on Peace and Law through United Nations in alerting the American people to the dangers inherent in the treaty-making power. ${ }^{36}$

32. "Foreign Policy," Congressional Quarterly Almanac 10 (1954): 255.

33. Ibid., 255.

34. Senate Judiciary Committee Hearings, 1953, note 7 above.

35. The role of the ABA has been discussed in an article by John Schmidhauser and Larry Berg, "The ABA and the Human Rights Conventions: The Political Significance of Private Professional Associations," Social Research 38 (1971): 362-410. See also "Foreign Policy," Congressional Quarterly Almanac 9 (1953): 233.

36. Congressional Record. 82nd Cong., 2d sess., 1952. Vol. 98, pt. 1, 910. 
A study of $A B A$ records reveals that the human rights treaties provided the initial impetus for the formulation of the amendment and a substantial reason for the $A B A^{\prime} s$ strong support of it. ${ }^{37}$

The ABA has consistently held a special status in the Senate's consideration of the human rights treaties. Its unique position was reflected in numerous statements by Senator Bricker in which he expressed his gratitude to the $A B A$ for their help, including their suggestions on the rewording of the amendment. ${ }^{38} \mathrm{ABA}$ members testifying in favor of the amendment were given special consideration; for example, they were invited by the Chairman of the Subcommittee to sit at his table. ${ }^{39}$ Special care was taken to consider their convenience for attending, and they were informed when important witnesses were testifying against the amendment. During the hearings, they frequently questioned other witnesses, a privilege normally reserved to members of the subcommittee. Arrangements were made so that one member could testify after all the opponents had finished their testimony in order to respond to any arguments that had been made. ${ }^{40}$ And, throughout the deliberations, $A B A$ positions on the amendment and on various treaties were cited by others as authoritative.

\section{A TYPOLOGY OF ARGUMENTS AGAINST RATIFICATION}

Previous sections have examined the arguments against human rights treaties found within the Bricker Amendment itself and within formal congressional deliberations. This section presents a typology of arguments offered in opposition to ratification of human rights treaties in the 1950s. While numerous hearings were held on the Bricker Amendment during this period, the single best source of anti-ratification arguments is the set of hearings held by the Senate Judiciary Committee in February and April of 1953. These were the most extensive hearings and they occurred when Senate support for the amendment was at its strongest. During these hearings, the Eisenhower administration made its commitment not to ratify the human rights treaties. This action made subsequent hearings less fruitful for our purposes, because it reduced the number of references by witnesses to the treaties.

Content analysis of the 1953 hearings (the procedures for which are described in greater detail in the next section) reaffirms the appropriateness of using these hearings to explore arguments against human rights treaties.

37. See Natalie Hevener Kaufman, Why the United States Doesn't Ratify Human Rights Treaties, forthcoming.

38. Senate Judiciary Committee Hearings, 1953, note 7 above, 158.

39. Ibid., 3.

40. Ibid., 158. 
TABLE 1

Analysis of Testimony in Support of The Bricker Amendment, Senate Judiciary Committee Hearings, 1953

\begin{tabular}{lccc}
\hline \hline Topic & $\begin{array}{c}\text { ABA } \\
\text { Testimony } \\
(n=208)\end{array}$ & $\begin{array}{c}\text { Percentage of } \\
\text { Non-ABA } \\
\text { Testimony* } \\
(\mathrm{n}=92)\end{array}$ & $\begin{array}{c}\text { All } \\
\text { Testimony } \\
(\mathrm{n}=300)\end{array}$ \\
\hline Human Rights Treaties & $49.5^{* *}$ & 51.1 & 50.0 \\
General Abuse of Treaty Power & 31.2 & 46.7 & 36.0 \\
Executive Agreements & 11.1 & 0.0 & 7.7 \\
Other*** & 8.2 & 2.2 & 6.3 \\
\hline
\end{tabular}

*Included in this category were representatives from the following organizations: Veterans of Foreign Wars of the United States, New Orleans State, American Flag Committee, and National Society of the Daughters of the American Revolution.

**Figures were computed by dividing the number of pages of testimony devoted to each topic by the total number of pages of testimony. The hearing included 300 pages of testimony in support of the Bricker amendment.

***The "Other" category includes other topics discussed by witnesses, discussions related to the procedure of the hearings themselves, and supplementary materials provided by the witnesses-such as texts of treaties and lists of organizations and countries.

Each page of testimony in support of the Bricker Amendment was coded according to the dominant topic of discussion. The results indicated a clear focus on human rights treaties. According to Table 1, the topic of human rights treaties accounted for 50 percent of the testimony. The other major issues of the hearings, executive agreements and the general abuse of the treaty-making power, together accounted for 43.7 percent. Also clear from the table is the significance of the role of the ABA. The testimony of members of the ABA's Special Committee on Peace and Law through the United Nations accounted for 69 percent of all testimony in support of the Bricker Amendment. The statements used in the remainder of this section to exemplify the arguments proposed are drawn almost entirely from this $A B A$ testimony.

\section{Diminish Basic Rights}

The most frequently mentioned arguments against human rights treaties was that the treaties would diminish basic rights. They reflect a lower standard of rights, either intentionally or as a result of inevitable compromises, and citizens of the United States stand to lose rather than gain from ratification of the treaties. The argument rests on the contention that once a human rights treaty is ratified, constitutional protections would be superceded. Ar- 
thur J. Schweppe, chair of the ABA Committee on Peace and Law through the United Nations, stressed this idea in his testimony: "The limitations in the first amendment with respect to freedom of speech, press, and religion are only limitations on Congress. They are not a limitation on the treatymaking power." 41 And Frank Holman, one-time ABA president, presented this argument dramatically:

the "internationalists" and the State Department move step by step-first aspirations, then ratification of these aspirations in treaty form, then international courts to enforce the aspirations. Thus our internal rights under our own Constitution, and Bill of Rights, are to be undermined step by step and will continue to be undermined unless the American people shut off this insidious process by an appropriate constitutional amendment. ${ }^{42}$

Various specific rights which were thought to be endangered, including most of the rights in the Bill of Rights, were discussed throughout the hearings. The testimony of ABA member Eberhard Deutsch on the freedom of the press conveys the flavor of these attacks: "[the treaties] contain the festering germs of destruction of a free press beyond the antiseptic properties of the first amendment." 43

\section{Violate States' Rights}

Another frequently cited objection to the human rights treaties was the alleged threat they posed to states' rights. The treaties, it was argued, would legitimize federal action in areas formerly reserved to the states. Some opponents identified supremacy of the federal government as the ultimate objective of the treaties. Deutsch stated clearly:

it is impossible to overemphasize the significance of present constitutionally possible abuses of the treatymaking power in the United States. The unquestionable objective of at least some of the opponents of constitutional limitation of that power is early elimination of State and local political entities except as administrative agencies of the Nation. . . . The gilding of multipartite treaties with such idealistic immediate goals as the prevention of genocide and the promotion of human rights cannot conceal their underlying long-range objective to destroy local government while expanding the sphere of national power. ${ }^{44}$

41. Ibid., 59.

42. Ibid., 143. Holman was president of the ABA from 1948 to 1949. He led a campaign, beginning in 1947, to alert the country to the dangers of "treaty law." This campaign targeted the United Nations human rights treaties as a threat to the American system and identified lawyers as the primary actors in halting the development and ratification of these treaties.

43. Ibid., 116.

44. Ibid., 115, 116. 
Federal action with respect to civil rights was very much on the minds of those supporting the Bricker Amendment. Frank Holman described his concern:

[A treaty] can increase the powers of the Federal Government at the expense of the States. For example, in the so-called field of civil rights, a treaty can do what the Congress has theretofore refused to do. The Congress has to date refused to enact the civil rights program..$^{45}$

He went on to explain that the federal government could accomplish this objective through ratification of the human rights treaties. Deutsch articulated the common concern that the treaties would be used specifically to legitimize federal legislation on racial matters: "and the same instrument has recently been cited with great force as a prohibition of race segregation in the District of Columbia, in Kansas, and in other States." ${ }^{\prime 46}$

A common metaphor for the treaties often heard during the hearings was that of the Trojan Horse. Deutsch explained the metaphor well:

the treaty clause of the Constitution (article VI) [is] as a 'Trojan Horse,' ready to unload its hidden soldiery into our midst, destroying State laws and constitutions and leaving behind the wreckage of the dream of the Founding Fathers which envisioned maintenance of the established constitutional balance between State and Federal power, and preservation of the Bill of Rights intact.77

Some of the specific states' rights which were mentioned during the hearings as being in danger of encroachment were the rights to restrict land sales on the basis of race and national origin, set criminal and civil liabilities, determine the political rights of women, establish qualifications for public school teachers, and regulate membership in the medical and legal professions-which seemed especially unsettling to the testifying ABA members. ${ }^{48}$

\section{Promote World Government}

A third argument which was made frequently during the hearings was that human rights treaties constituted a move in the direction of establishing a world government. An ABA memorandum on the amendment was included in the testimony of Vernon Hatch and referred to the issue of world government.

\footnotetext{
45. Ibid., 145.

46. Ibid., 116.

47. Ibid., 119.

48. Ibid., 100, 120-23, 1107, 1131, 1132.
} 
Not only is the treaty power a threat to the States, it is a threat to the very Federal Government itself through the pressures of inter-nationally minded groups who would favor erecting a world government by the treaty route in whose favor we would abdicate much, if not all, of our sovereignty. . . .49

The danger evoked by Holman is of Americans waking up to find that they are living under world government. "We [could] have had a full-fledged world government overnight, and this is exactly what may happen under so-called treaty law unless a constitutional amendment is passed protecting American rights. . . . 50 Opponents of the amendment are portrayed as at best misguided and at worst ill-intentioned. George Finch's testimony is addressed to the former.

The adoption of the proposed constitutional amendment now before this committee relating to the treatymaking power would stop the prevailing trend to regard the United Nations as but the first step in the ultimate establishment of a world government in which the United States would occupy the position of a province. ... Now, the so-called liberals, the people who are opposing things that we are trying to do here would take us back into that era from which we emerged 300 years ago and subordinate our sovereignty, which means our freedom and our independence, to some foreign power in which we would have but one vote among many. ... .51

The latter view of the opposition is presented by Deutsch.

It is difficult to believe that objections to a constitutional bulwark against direct legislative participation by Poland and the Argentine in the local affairs of Louisiana and North Dakota and Ohio and Utah can be rooted in good faith. ${ }^{52}$

\section{Subject Citizens To Trial Abroad}

A continuing argument which aroused strong emotional response was the allegation that human rights treaties would lead to the trial of Americans in foreign courts. The major points of the allegation are described in Ober's testimony.

Among the 200 treaties that are being proposed is a treaty creating an international criminal court . . . a court composed of all but one of foreign judges, including judges from other countries who have no conception of our independent judiciary but think only of the judges as an arm of the political government.53

49. Ibid., 105.

50. Ibid., 143.

51. Ibid., 1108.

52. Ibid., 115.

53. Ibid., 168. 
As implied in the statement above, aversion to the idea of trials abroad carried with it a suspicion of foreign judicial systems and fear of the loss of procedural safeguards.

Meanwhile, the Genocide Convention is still on the agenda of the Senate for ratification, which, if ratified, would, among other things, commit us to the principle of the trial of American citizens in foreign courts . . . where our constitutional trial procedures and Bill of Rights would not operate. ${ }^{54}$

\section{Threaten Our Form of Government}

A fifth line of opposition to the human rights treaties was the allegation that they constitute a serious threat to our form of government. In addition to the disintegration of the line between federal and state powers, testimony before the Senate Judiciary Committee frequently predicted the general destruction of the American political system. The ABA Standing Committee report exemplified this line of reasoning, suggesting that "the real significance" of the amendment was "the preservation of our form of government against the abuse of the treaty power. ${ }^{155}$ Holman made a similar argument speaking of the human rights treaties and the need for the amendment.

Our own Bill of Rights forbids the Congress to change our basic rights but as the Constitution now stands it does not prevent our basic rights from being changed by a treaty made by the treatymaking agency which consists of the President and two-thirds of the Senators present and voting. This is the loophole in the Constitution that we now face and through which the internationalists propose to move and by treaty law change and level out our American rights (both State and individual) and thereby change our form of government. ${ }^{56}$

\section{Enhance Soviet/Communist Influence}

McCarthyism and the Cold War, which dominated the politics of the early 1950s, had a clear impact on the debates concerning the human rights treaties. Arguments related to the communist scare appeared in two different forms. One, closely related to the preceding argument, emphasized the direct threat posed by the Soviet Union. The treaties were presented as manifestations of Soviet efforts to undermine the American system. Again the testimony of Finch is instructive:

54. Ibid., 143-44.

55. Ibid., 47.

56. Ibid., 144. 
the United States should not participate in the negotiation of treaties, the effect of which would be to build around us a wall of socialistic and communist containment in anticipation of the withering away of our principles of human freedom and of the decay of the free institutions we have established to secure them. Are we so certain of our internal strength that we can resist indefinitely the communistic softening to which we are being subjected? ${ }^{\text {s7 }}$

More frequently, the spectre of communism appeared in allegations that the treaties contain socialist rights. The dangers outlined were multiple.

One of the first documents produced under this program of world-wide reform ... was the so-called Declaration of Human Rights. ... This declaration, among other things, is a complete blueprint for socializing the world, including the United States. Article 23 provides that everyone has the right to "just and favorable conditions of work and to protection against unemployment" and that everyone has the right to "just and favorable remuneration. ..." The purpose provided was to liquidate our individual enterprise system. ${ }^{58}$

Senator Bricker also presented his concern that the treaties would alter our "control over our domestic, social, and economic rights, world medicine, socialized medicine. . . I am trying to plug that loophole so that there will be no possibility of it." 59 He also addressed the issue by stating: "You know that the American Medical Society is greatly disturbed about the possibility of socialized medicine in this country coming in by the back door of treaties." ${ }^{\prime 60}$

\section{Infringe on Domestic Jurisdiction}

The human rights treaties were consistently criticized on the grounds that they infringed upon the United States domestic jurisdiction and violated the domestic jurisdiction clause of the United Nations Charter. Some opponents believed that the treaties involved matters that were essentially domestic and beyond the legitimate reach of an international organization. Holman made this claim in citing a member of the United Nations Human Rights Division:

who stated that what the Commission [on Human Rights] was proposing constituted an intervention in matters "within the domestic jurisdiction" of the member states. And he exposed this whole program which has since been under way in the United Nations, in my opinion not a program of peace at all, but a program for meddling in the affairs of the member states. ${ }^{61}$

57. Ibid., 1109-110.

58. Ibid., 136.

59. Ibid., 155.

60. Ibid., 112.

61. Ibid., 133. 
Deutsch expressed the contention that domestic jurisdiction was threatened by human rights treaties:

With similar suavity, albeit with greater logic, we were assured that section 7 of article Il of the Charter of the United Nations gave us added protection against interference by that world organization in our domestic affairs. But today even the opponents of constitutional limitations on treatymaking power can no longer sustain their confidence in understandings and reservations as adequate safeguards against the destructive potentialities of international conventions. ${ }^{62}$

\section{Create Self-Executing Obligations}

A further, somewhat technical argument, made primarily by lawyers, was that the treaties were self-executing. Self-executing treaties need no implementing legislation to be effective and can be cited and applied by domestic courts. As we have seen, one provision of the Bricker Amendment was that no treaty would be implemented without congressional legislation. Finch explained this purpose of the amendment. "The purpose of the American Bar Association amendment [is] to make all treaties non-self-executing as internal law and thus require legislation to make them internally effective." ${ }^{\prime 63}$ He also elaborated upon the special problems of the human rights treaties as self-executing.

That is why we had all this discussion about the Treaty on Human Rights. ... The United Nations itself cannot by any declaration or resolution or draft treaty make law within the United States. When they do try to do it, it is through the treaty method because of our peculiar provision of our Constitution. What we are trying to do now is to plug that gap so they cannot do it that way and would be obliged to resort to legislation by the whole Congress. ${ }^{64}$

\section{Increase International Entanglements}

Other arguments were generated by antipathy toward the United Nations and United Nations agencies and a fear of foreign entanglements. Non-ABA witnesses were particularly outspoken about their suspicions of the United Nations activities, especially action related to human rights. For example, Reverend DeLoss Scott appeared on behalf of the American Council of Christian Churches and spoke against the United Nations and especially

62. Ibid., 115.

63. Ibid., 1123.

64. Ibid., 1148. 
against the Covenant on Human Rights and the Genocide Convention. He cited the opening words of the Charter which "brings the United Nations down into the realm of human affairs, affairs which affect our daily lives as individuals" and praised Senator Patrick McCarran for his regret "to my dying day that ever voted for the U.N. Charter."165

W. L. McGrath, speaking on behalf of the United States Chamber of Commerce, presented a very critical view of the United Nations and its agencies. In speaking of the treaties produced by the United Nations, he said:

Don't you see how devious these people plan how they move into the back door if they can't deal with you at the front door? They go around to the back door. And that is dangerous... The issue cannot be dismissed by saying casually that of course even a bare quorum of the Senate could not conceivably ratify anything that would not be in conformity with the Constitution. ${ }^{66}$

Associated with the neo-isolationism of the time was an ethnocentrism, a suspicion of foreign states and a fear of entangling alliances. Holman expressed the first of these concerns. "Why should we overlay our inherent and precious rights and freedoms with a pattern of international rights drawn to suit the concepts of more than 60 nations with varying and antagonistic concepts." ${ }^{\prime 67}$ And Mrs. Enid Griswold, representing the National Economic Council, referred to the second of these issues. "The role of world leadership which ... has been thrust upon us, can best be fulfilled by preserving our American Republic and by limiting our international commitments to what we can do without weakening ourselves." ${ }^{16}$

\section{CONTEMPORARY OPPOSITION IN PERSPECTIVE}

To what extent, then, do the arguments against human rights treaties developed in the 1950s, which crystalized during the debate over the Bricker Amendment, continue to influence contemporary congressional deliberations? We have explored two sources of data in addressing this question. First, we have compared the 1953 hearings on the Bricker Amendment with roughly comparable contemporary hearings. Second, we have interviewed congressional staff members in an attempt to assess the importance of the Bricker legacy from their perspective.

65. Ibid., $273-74$

66. Ibid., 565.

67. Ibid., 142.

68. Ibid., 176. 


\section{Stability of Arguments Over Time}

Two sets of congressional hearings were selected for content analysis. As already noted, the Bricker hearings in 1953 represent the best source of arguments against human rights treaties from the 1950s. For more contemporary arguments, the single best source is the record of hearings held in 1979 concerning four human rights treaties which were sent to the Senate by President Carter in $1978 .{ }^{69}$ Content analysis of the hearings, which included testimony from members of Congress as well as other witnesses, was limited to those witnesses who either supported the Bricker Amendment in the 1953 hearings or opposed any of the treaties discussed at the 1979 hearings.

The content of the testimony of each of the witnesses was analyzed according to the list of major lines of arguments, and minor variations on those arguments, presented in the Appendix (which summarizes the discussion from the preceding section). All specific references to one or more human rights treaties were examined, and each new appearance of an argument was assigned to the proper category. ${ }^{70}$ Hearings were coded independently by two investigators, and inconsistent codings were analyzed further. Results of the analysis are presented in Table 2, which provides figures which indicate, of the total number of arguments made in the hearings, the percentage of times each individual argument appeared.

The results in Table 2 indicate the consistency of arguments made in opposition to human rights treaties, along with some interesting variation over time. Perhaps the clearest indication of consistency is that 93.5 percent of the arguments which appeared in the 1979 hearings were essentially unchanged from 1953. In addition, the relative frequency of arguments did not change significantly. The two principle arguments in both periods - that the treaties would diminish basic rights and violate states' rights-held the same rankings and accounted for a substantial proportion of the total arguments (38.2 percent in 1953 and 56.1 percent in 1979). The only arguments which declined dramatically in frequency were concerns that the treaties would subject citizens to trial abroad and would increase international entanglements. The remaining arguments from 1953 were all clearly evident in the 1979 hearings, with their relative frequencies not significantly altered.

69. The four treaties were: the two covenants, the American Convention, and the Racial Discrimination Convention.

70. For similar efforts see Ole Holsti, Content Analysis for the Social Sciences and Humanities (Menlo Park, California: Addison-Wesley Publishing Company, 1969); and Steven del Sesto, "Nuclear Reactor Safety and the Role of the Congressman: A Content Analysis of Congressional Hearings," Journal of Politics 42 (1980): 227-41. 
TABLE 2

Analysis of Arguments Made Against Human Rights Treaties, Based on Senate Hearings in 1953 and 1979

\begin{tabular}{lcccc}
\hline \hline & \multicolumn{2}{c}{1953} & \multicolumn{2}{c}{1979} \\
& Percentage & Rank & Percentage & Rank \\
\hline Diminish Basic Rights & $21.4 \%$ & 1 & $32.7 \%$ & 1 \\
Violate States' Rights & 16.8 & 2 & 23.4 & 2 \\
Promote World Government & 13.6 & 3 & 6.5 & 4 \\
Enhance Soviet/Communist Influence & 11.2 & 4 & 4.7 & 8 \\
Subject Citizens to Trial Abroad & 10.6 & 5 & 0.9 & 10 \\
Threaten Our Form of Government & 7.8 & 6 & 11.2 & 3 \\
Infringe on Domestic Jurisdiction & 6.5 & 7 & 5.6 & 6 \\
Increase International Entanglements & 5.1 & 8 & 0.9 & 10 \\
Create Self-Executing Obligations & 4.9 & 9 & 2.8 & 9 \\
Other & 2.1 & 10 & 4.8 & 7 \\
New 1979 Arguments & & & 6.5 & 4 \\
\hline Total & 100.0 & & 100.0 &
\end{tabular}

The two new arguments which appeared during the 1979 hearings reflected changes in the political and economic environment. The first new argument was a response to the increased number of uncompensated expropriations of United States assets abroad and the apparent effort by developing countries to legitimize them. This argument attacks the covenant provision on permanent sovereignty over natural resources. The United States representative throughout the drafting of the treaties argued that the wording might be interpreted as allowing expropriation of foreign investment without prompt and adequate compensation. Senator Jesse Helms was especially incensed about this provision, which he argued "would for the first time legitimize the unlawful expropriation without compensation or arbitrary seizure of Americans' property overseas." ${ }^{\prime \prime 1}$

The second new argument arose from domestic opposition to the women's movement, particularly the ERA. Phyllis Schlafly was vehement in her contention in that the treaties would deprive American women of important protections. For example, she argued that the Covenant on Civil and Political Rights would obligate the federal government to "register and conscript

71. U.S. Congress. Senate. Committee on Foreign Relations. Hearings on International Human Rights Treaties. 96th Cong., 1st sess., 1979. S. Rept. 8. 
women for military service" whenever men were registered and conscripted. She also linked the destruction of women's rights to the loss of states' rights:

[This covenant would change the marriage laws of most of the 50 states by imposing 'equality of rights' as between the spouses during marriage. ... The Covenant would also take away the rights of state legislatures in the fifty states to enact and retain the marriage laws desired by the people of each state and devised in a process of democratic decision-making. ${ }^{72}$

\section{Factors Inhibiting Action}

A second avenue for exploring contemporary arguments against human rights treaties is to assess the current opinions of members of the Senate Foreign Relations Committee. We interviewed the primary foreign policy staff members of ten of the sixteen committee members in the 98th Congress. Respondents were guaranteed anonymity. All unattributed quotations in this section are from these interviews. Interviews ranged in duration from forty to ninety minutes and were conducted in January 1984.

At the time of the interviews, congressional action on human rights treaties appeared to be extremely unlikely. While still formally pending before the Senate Foreign Relations Committee, the treaties were not on the congressional agenda. Supporters of the treaties did not appear to be planning any action to stimulate congressional consideration. They saw little political benefit to be gained in advocating the treaties, and feared the potential political controversy as the latent opposition to the treaties once again became vocal. Supporters were convinced that "if they brought [the treaties] up, they would be filibustered, and there would be efforts to amend them."

One clear finding is that, whatever the influence of the Bricker Amendment, it is not often based on direct knowledge about the Bricker debate. Few of the staff members interviewed were even familiar with the specifics of the debate in the 1950s. Instead, the legacy lies in the near-universal perception that human rights treaties are inherently controversial. As one respondent expressed it, what is "important is the perception of a given treaty . . . everything gets categorized." Anything associated with human rights is viewed as "not immediate, apparently controversial, so we can push it aside." Another staff member indicated that "it was the Bricker Amendment controversy, and the incredible knock-down drag-out fight that Eisenhower had in fighting that off, that I think formed a lot of the basic background."

What would it take to overcome this legacy? Respondents were asked to rank five factors according to their importance in explaining the current situation of the human rights treaties. According to Table 3, the most im-

72. Ibid., 105, 108. 
TABLE 3

Rankings of Factors Inhibiting Passage of Human Rights Treaties, Based on Interviews with Senate Staff, 1984

\begin{tabular}{lccc}
\hline \hline Factor & \multicolumn{3}{c}{ Staff Members } \\
& $\begin{array}{c}\text { Republican } \\
(n=7)\end{array}$ & $\begin{array}{c}\text { Democratic } \\
(n=3)\end{array}$ & $\begin{array}{c}\text { All } \\
(n=10)\end{array}$ \\
\hline Support of Administration & $1.9^{*}$ & 2.0 & 1.9 \\
Internal Senate Politics & 2.3 & 3.0 & 2.5 \\
Public Opinion & 3.6 & 1.3 & 2.9 \\
Content of Treaties & 3.3 & 4.7 & 3.7 \\
Current International Situation & 4.0 & 4.0 & 4.0 \\
\hline
\end{tabular}

*Figures are the average ranking (out of a possible 5) given to this factor by each category of staff.

portant factor was the position of the president. Respondents, particularly Republican respondents, perceived that the lack of interest on the part of the Reagan administration was the most important factor in explaining why the Senate had no plans to consider, much less approve, the treaties. Presidential support was viewed as an essential ingredient for passage: "the administration has to be mobilized for the Congress to be mobilized;" "the President would have to be behind them;" "a strong presidency to twist arms is the only way for [human rights] treaties to get through."

Respondents often referred to the Carter administration, which did sign three human rights treaties and formally supported their passage in the Senate. The Carter administration's support of the human rights treaties, however, eventually became secondary to the support of other treaties: "the President only has so many cards to play, and Carter was sidetracked by Panama Canal and SALT II." In any case, a decision to take an active role in advocating human rights treaties is a difficult one to make, in light of the perceived meager political benefits. Advocating the treaties would be "politically costly" without tangible rewards: "the essential element [inhibiting passage] is a lack of political constituency... people cannot see a direct link between the treaties and their overall interest."

Debate over the Genocide Treaty in 1984, which occurred subsequent to the completion of the interviews, certainly supports this view of the role of the executive branch in promoting consideration of human rights treaties. President Reagan's unexpected endorsement of the Genocide Treaty resulted in the almost immediate Senate consideration. The Senate Foreign Relations Committee's passage of the treaty occurred just a few weeks later, despite universal pessimism on the part of Senate staff earlier that year. 
A second general conclusion supported by Table 3 is that the actual content of the treaties is not viewed as the primary determinant of the current situation. Perception is important, not content. In general, staff members had not read any of the treaties and were unfamiliar with their content and objectives. They were, on the other hand, very clear about the expected response of opponents within and behind the Senate. Reactions to the treaties were based on their perceived controversiality, the absence of a large and powerful supporting constituency, and the lack of active presidential support-not on the provisions of the documents. In matters of great controversy and small tangible return, proponents of the treaties generally preferred to remain inactive rather than to commit scarce resources of time, favors, and energy.

\section{CONCLUSION}

In this article we have analyzed the early opposition to human rights treaties in the United States Senate and the residual effect of this opposition on contemporary consideration of the treaties. We have documented that opposition to human rights treaties was central in the movement during the 1950 s to amend the treaty provisions of the Constitution. During the effort to pass the Bricker Amendment, arguments against human rights treaties were elaborated in their fullest form and were given national attention. Because of the strong historical support of the United States for human rights treaties, and the leading role this country played in drafting them, many had assumed that the question before the Senate would be "Why not ratify the treaties?" The hearings on the Bricker Amendment effectively turned that question around. Proponents of the treaties were put on the defensive, having to answer a host of legal and political criticisms. By the end of the hearings, these arguments had crystallized into a set of objections which, based on our analysis of the stability of arguments over time, appeared essentially unchanged in the 1979 hearings and which are still being cited today.

These long-standing objections are not easily overcome-fears once raised are not easily laid to rest. The recent experience of the ABA provides a good illustration. Although very successful in the 1950s in dramatizing what they perceived to be the dangers of the treaties, the ABA in the mid1970 s reversed its position on all of the human rights treaties covered in this study and recommended Senate approval with reservations. ${ }^{73}$ Yet the

73. The ABA approved the Supplementary Slavery Convention in 1967; the Genocide Convention (with specified understandings) in 1976; the Racial Discrimination Treaty (with reservations) in 1978; the American Convention on Human Rights (with reservations) in 1979; and both Covenants on Human Rights (with reservations) in 1979. 
treaties still have not received sustained Senate attention. The ABA's currently active campaign in support of the treaties-to persuade the Senate that the "dangers" inherent in the treaties have now disappeared-will certainly be a difficult task, given the legacy of their original negative campaign which provided the underpinning for decades of opposition.

The arguments of the 1950s fostered the perception that human rights treaties were controversial and potentially dangerous. These arguments appear today despite deep and widespread changes in United States domestic law on human rights and the ascendancy of human rights in regional and international fora. Continued United States inaction on human rights treaties confuses most of our citizens and many of our allies. Yet ratification remains unlikely. The personal campaign of Senator Bricker to "bury" human rights treaties continued as late as 1971, when he wrote to the Senate Foreign Relations Committee during their hearings on the Genocide Convention: "I do not want to live to see the day that the Constitution of the United States and the Bill of Rights becomes a mere scrap of paper, and this treaty, if ratified, would be the beginning of such a process." ${ }^{174}$ The legacy of the Bricker Amendment appears to be continued opposition to human rights treaties, continued neglect of them by the United States Senate, and continued evidence of the success of Senator Bricker's burial tactics.

\section{APPENDIX \\ ARGUMENTS AGAINST U.S. RATIFICATION OF HUMAN RIGHTS TREATIES}

1. DIMINISH BASIC RIGHTS: Human rights treaties reflect a lower standard than is currently guaranteed; they will take away U.S. rights and protection.

1a. endanger the Bill of Rights

1 b. constitute an attack on the concept of inalienable rights

1c. deprive U.S. citizens of freedom of assembly

1 d. deprive U.S. citizens of freedom of religion

1e. deprive U.S. citizens of freedom of the press

1f. deprive U.S. citizens of freedom of speech

1g. deprive U.S. citizens of the right of private property

$1 \mathrm{~h}$. deprive U.S. citizens of the right to private medical care and to operate private medical practice

74. U.S. Congress. Senate. Committee on Foreign Relations. Subcommittee on the Genocide Convention. Hearings on the Cenocide Convention. 92nd Cong., 1st sess., 1971. 13739. 
2. VIOLATE STATES' RIGHTS: Human rights treaties violate Constitutional protection of states' rights. They will give the Federal government powers meant to be retained by the states.

2a. land ownership by aliens may be allowed

$2 \mathrm{~b}$. professional medical and bar practice by aliens may be allowed

2c. there is no federal-state provision in the treaties

2d. racial matters

2e. other states' rights

3. PROMOTE WORLD GOVERNMENT: Human rights treaties are being used to move toward world government.

3a. open us up to criticism in international fora

3 b. require us to impose international standards, which would constitute an erosion of sovereignty

3c. subordinate us to foreign powers

4. ENHANCE SOVIET/COMMUNIST INFLUENCE: Human rights treaties foster communism, soviet policies, and socialist rights.

4a. Human rights treaties are a part of the Communist effort to take over the world.

4b. specific mention of the Soviet Union

4c. contain socialist rights, including economic, social and cultural rights

4d. obligate governments to provide private sector services as public sector rights (food, shelter, clothing)

4e. challenge the free enterprise system (right to strike, form trade unions)

4f. anti-ILO

5. SUBJECT CITIZENS TO TRIAL ABROAD:

5a. deprive US citizens right to trial by jury

5b. anti-international criminal court

6. THREATEN OUR FORM OF GOVERNMENT: Human rights treaties will erode fundamental governmental powers.

6a. The Founding Fathers would not approve

6b. increase power of the president at the expense of Congress

$6 c$. result in loss of control over immigration

$6 \mathrm{~d}$. give president new power to seize property

7. INFRINGE ON DOMESTIC JURISDICTION: Human rights treaties contain subjects which infringe on domestic matters. 
8. INCREASE INTERNATIONAL ENTANGLEMENTS: Human rights treaties are the creation of the U.N. which is a suspect organization and will draw us into matters which should not concern us.

8a. Anti-U.N.

8b. Neo-isolationism

9. CREATE SELF-EXECUTING OBLIGATIONS: Treaties are self-executing. 9a. There is no non-self-executing provision in the treaties.

9 b. Other states can ratify without the treaties becoming domestic law; the U.S. cannot.

10. OTHER:

10a. Human rights treaties will undermine the ability of the U.N. to do its major job of security.

10b. Human rights treaties contain only the rights we already have and provide no additional protections for U.S. citizens.

10c. Experts say that human rights treaties should not be ratified.

11. NEW 1979 ARGUMENTS:

11a. Legitimate expropriation of U.S. property abroad

11b. Diminish the rights of U.S. women 